\title{
Contemporary issues and challenges of power sector in haryana
}

\author{
Kamaljit Singh', Jasvinder Kaur ${ }^{2}$ \\ Research Scholar, University School of Management, Kurukshetra University, Kurukshetral \\ Research Scholar, Department of Commerce, Kurukshetra University, Kurukshetra ${ }^{2}$ \\ Email:kamaljitsehjanusm17@kuk.ac.in, kaurjasvinder26jan@gmail.com
}

\begin{abstract}
In this paper, a discussion has been made about the current contemporary issues and challenges of the power sector in Haryana. The issues related to tariff rates, transmission and distribution losses, financial constraints \& NPA, capacity constraints, and aggregate technical and commercial losses are discussed. The Haryana Power Utilities (HPUs) are required to be changed adequately from substantial losses to the sound profits by taking legitimate activities for improving the financial efficiencies, and technical performance.
\end{abstract}

Keywords: power sector, issues \& challenges, tariff rate, at\&c and t\&d losses

\section{INTRODUCTION}

India is set for quick, supported development in energy demand. Power is one of the vital key drivers of financial advancement and assumes an urgent job in the financial advancement process. Energy engages social and financial advancement and furthermore adversely affects the earth. A non-stop, predictable, dependable and moderate supply of power is essential for financial improvement, standardized savings and open welfare. The accessibility and availability of moderate and subjective power offers fuel to the motor of monetary development. India is the third-largest producer (1,290 billion $\mathrm{KWh})$ and also the third largest buyer of electricity $(1,122 \mathrm{KWh}$ per individual) on the planet Singh and Vashishtha (2019).

\subsection{Power Scenario in Haryana}

The Haryana Electricity Reform Act, 1997 restructured the Haryana Electricity Board in 1998 into four utilities namely (1) Haryana Power Generation Corporation Limited (HPGCL), (2) Haryana Vidyut Parsaran Nigam Limited (HVPNL), (3) Uttar Haryana Bijli Vitran Nigam Limited and (4) Dakshin Haryana Bijli Vitran Nigam Limited. For regulating these utilities a commission named Haryana Electricity Regulation Commission (HERC) was setup Singh and Vashishtha (2019). Haryana is an agriculture state with over $60 \%$ population occupied with cultivating. The wind speed is likewise deficient to endeavor and use for power generation. The entire state is subject to the restricted warm age limit introduced inside the state and hydropower from the together possessed projects. The aggregated losses went up to Rs. 1358.67 crores and the fundamental reasons distinguished for this, were a un-gainful duty, power supply at financed rates, low plant load factor (PLF) in power stations, and excessive transmission and distribution (T\&D) losses and so forth. 


\section{Figure 1: Per Capita Electricity Consumption}

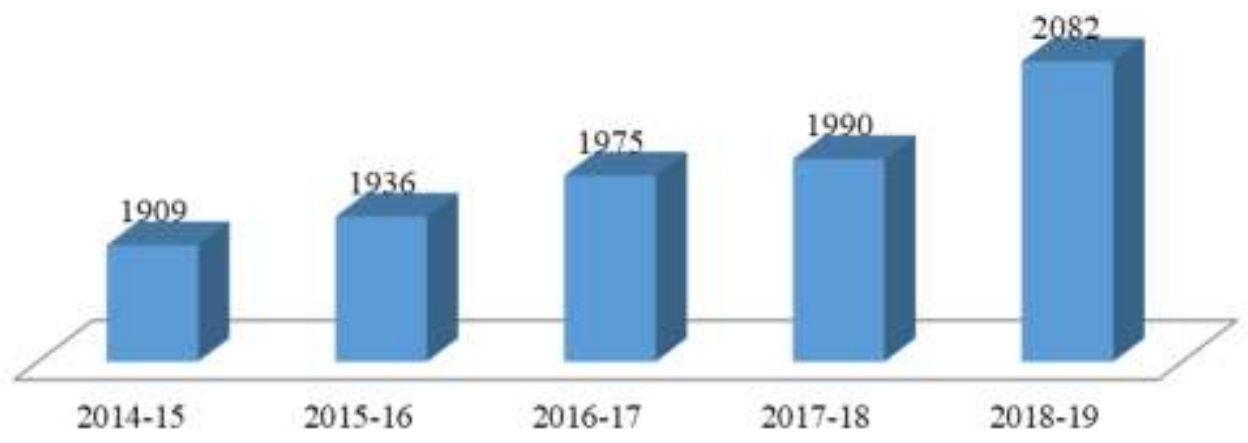

The per capita electricity consumption had increased gradually since 2014-15 to 2018-19. Despite these issues related to tariff rates, transmission and distribution losses, financial constraints \& NPA, capacity constraints, and aggregate technical and commercial losses are becoming main reasons which affect performance of power sector, respectively. So, in this paper, a discussion has been made about the current contemporary issues and challenges of the power sector in Haryana's context.

\section{Review of Literature}

There is considerable amount of literature available on contemporary issues and challenges of power sector in India. Purakayastha (1993), considered a new power arrangement and inspected whether the proposed arrangement prompt the long haul wellbeing of the power division or it will be more regrettable than the malady. Author found out that the legislature of India had obviously discovered the standard arrangement welcome capital, both outside and Indian. Reddy and Sumithra (1997), investigated Karnataka's capacity division - the current circumstance and patterns of power demand and supply, Karnataka Electricity Board's money related issues, the critical arrangement' and specialized achievements in the improvement of Karnataka's influence area. Das and Parikh (2000), put forth a defense contemplate on all variables to make Maharashtra State Electricity Board (MSEB) economically suitable and across the country the yearly loss of MSEB was evaluated at Rs 10,684 crore in 1997-98. Santhakumar (2003), contemplated the power division changes started by the government in Kerala between 1996-2000, for upgrading age limit and improving the effectiveness of the state power board. Bhattacharyya (2007), examined the energy area difficulties to give a general understanding of a part of the board issues and this examination pursued an explanatory deductive technique to break down the issues utilizing existing writing as the wellspring of data. Dasaraju and Murthy (2011), broke down the significance of intensity part, purchaser utility, demand, and age of intensity. Authors concluded that in India the majority of the power utilization was by the farming area, where the rate of income was exceptionally low. So, from the above-discussed literature it can be revealed that there is insufficient number of studies in the context of Haryana.

\section{Methodology}

The methodology of the paper is based on secondary data such as books, journals, newspapers, and internet. The data of per capita electricity consumption was retrieved from www.cea.nic.in and information about the Haryana Power Sector had been collected from the Central Electricity Authority (CEA) and Energy Statistics, 2019.

\section{Issues and Challenges}

The poor execution of Haryana Power Corporation is an immediate after effect of low usage limit of thermal plants, extremely high transmission, and commercial losses and non-recovery of defaulting sum in the most politically sensitive districts. So some important issues are discussed following:

A. Tariff Rates: Tariff is the evaluating structure a retailer charges a client for energy utilization. It's separated into two sections:

\# The fixed charge for the everyday supply of energy to your premises

* The variable charge for the measure of energy you use 
The variable charge relates specifically to the amount you expend. Duties change contingent upon your energy merchant. The power levies rely upon the accompanying variables like;

* Type of burden

\# Time at which load is required.

\# The control factor of the heap.

* The measure of energy utilized.

B. Transmission and Distribution Losses: Despite significant improvement since the turn of the century, India has one of the most abnormal amounts of power transmission and distribution (T\&D) losses on the planet. T\&D losses speak to the power that is produced yet does not achieve expected clients. Power losses are the consequence of specialized wastefulness and burglary. Specialized losses happen on account of the opposition of wires and hardware as power goes through. The majority of India's T\&D losses resulting from a burglary, which happens when expended power isn't represented. Power is normally stolen by bypassing or altering the meter, or by paying off utility meter peruses or charging specialists.

C. Financial Constraints and NPA: NPAs of state-run banks alone toward the finish of last September rose to Rs 6.3 lakh crore. Amid the dialogs with the different Ministries/Banking Institutions/Stakeholders, the accompanying issues were distinguished which are in charge of monetary worry in the said warm power ventures (Standing Committee On Energy, 2017-18):

\# Non-accessibility of Fuel:

* Cancellation of coal square.

* Projects set up without Linkage.

\# Lack of enough PPA by states

* The inability of the Promoter to mix the value and working capital

* Contractual/Tariff related debate

* Issues identified with Banks/Financial Institutions (FIs)

\# Delay in undertaking executions prompting cost invade.

D. Capacity Constraints: Haryana is needy upon restricted warm age limit as the State has restricted accessibility of normal assets, low potential for hydro age, insufficient wind velocity, absence of the ability to tackle sun oriented assets. Wasteful age of power, transmission, and circulation of power supply and wasteful utilization of intensity has made a circumstance of significant pinnacles hours and energy deficiencies in Haryana. The low quality of power supply has additionally affected the creation of the economy.

E. Aggregate Technical and Commercial Losses:

(i) Technical Losses

\# Overloading of existing lines and substation gear

* Low HT: LT lines proportion higher measure of current stream in the framework results in higher misfortunes.

* Poor fix and support of gear

* Non-establishment of adequate capacitors/responsive power gear

(ii) Commercial Losses

* Low metering/charging/accumulation proficiency

\# Theft, pilferage of power and altering of meters

\# Low responsibility of representatives

* Absence of Energy Accounting and Auditing

\section{CONCLUSION}

Haryana is needy upon constrained thermal age limit as the State has restricted accessibility of characteristic assets, low potential for hydro age, insufficient wind velocity, absence of the ability to tackle solar resources. The wasteful age of electricity, transmission, and distribution of electricity supply 
and wasteful utilization of power has made a circumstance of substantial peaks hours and energy deficiencies in Haryana. So, the Haryana Power Utilities (HPUs) are required to be changed adequately from substantial losses to the sound profits by taking legitimate activities for improving the financial efficiencies and technical performance.

\section{REFERENCES}

[1] Bhattacharyya, S. C. (2007). Energy sector management issues: an overview. International Journal of Energy Sector Management.

[2] Das, A., \& Parikh, J. (2000). Making Maharashtra State Electricity Board Commercially Viable. Economic and Political Weekly, 1201-1208.

[3] Dasaraju, H., \& Murthy, K. S. (2011). Efficiency of Indian Power Sector an Analysis of its Performance and Problems. International Journal of Management \& Business Studies, 1(3), 85-91.

[4] Purakayastha, P. (1993). New Power Policy: Bankrupting the Power Sector. Economic and Political Weekly, 955-957.

[5] Reddy, A. K., \& Sumithra, G. D. (1997). Karnataka's power sector: some revelations. Economic and Political Weekly, 585-600.

[6] Santhakumar, V. (2003). Impact of distribution of costs and benefits of non-reform: case study of power sector reforms in Kerala between 1996 and 2000. Economic and Political Weekly, 147-154.

[7] Singh, K., \& Vashishtha, S. (2019). Performance analysis and initiative policies: a study of Indian power sector. American Journal of Economics and Business Management, 2(4), 163-179.

[8] Singh, K., \& Vashishtha, S. (2019). Empowering the power sector through uday: A study of Haryana. ZENITH International Journal of Multidisciplinary Research, 9(5), 1-7.

[9] Singh, K., \& Kumar, V. (2020). Dynamic linkage between nifty-fifty and sectorial indices of national stock exchange. American Journal of Economics and Business Management, 3(2), 17-27. 